\title{
Acute Iron Poisoning in Children: Role of Chelating Agents
}

\author{
DAVID G. D. BARR,* M.B., CH.B., M.R.C.P.ED., D.C.H. ; DAVID K. B. FRASER, † M.B., B.S., M.R.C.P.ED.
}

Brit. med.F., 1968, 1, 737-741

With the development of the iron-chelating agents; desferrioxamine and diethylenetriamine penta-acetic acid (D.T.P.A.), it was appreciated that these substances were potentially valuable in the treatment of acute iron poisoning (Rubin and Princiotto, 1960 ; Bannerman et.al., 1962 ; Moeschlin and Schnider, 1963 ; Brit. med. F., 1963 ; Lancet, 1964).

In the past four years a number of reports have been published on the usefulness of these drugs in clinical practice (Henderson et al., 1963 ; Gokulanathan et al., 1963 ; Santos and Pisciotta, 1964 ; Dugdale and Powell, 1964 ; Shapiro and Barbezat, 1964 ; McEnery and Mack, 1964 ; Whitten et al., 1965 ; Jacobs et al., 1965 ; McEnery and Greengard, 1966). Several authors have stressed the need for further experience in this form of treatment, particularly in determining the optimal dosage schedule for desferrioxamine, and present regimens have been considered to be tentative (Ciba, 1965; Brit. med. F., 1965 ; Whitten et al., 1965).

This paper presents an account of experience with 16 child- ren suffering from iron intoxication of varying degrees. An attempt is made to achieve a critical appraisal of the chelating drugs by considering their biochemical effectiveness, the incidence of side-effects, and their influence on mortality and morbidity.

\section{Methods and Clinical Material}

Serum iron estimations were determined by a colorimetric method using dipyridyl (Ramsay, 1958). Successive 24-hour urine collections were estimated for total iron content. Initially, the method used involved the colour reaction with thioglycolic acid (Tompsett, 1965, 1966). In recent cases an assay involving a modification of the dipyridyl method has been employed as suggested by Ciba (1965).

The patients, ranging in age from 1 to $6 \frac{1}{2}$ years, had accidentally ingested indefinite amounts of ferrous sulphate or ferrous gluconate. The children may be subdivided into groups

- Senior Registrar in Medical Paediatrics, Royal Hospital for Sick Children, Edinburgh 9.

t Registrar in Medical Paediatrics, Western General Hospital, Edinburgh 4. Present address: Royal Brisbane Children's Hospital, Brisbane, Australia.

Requests for reprints should be sent to Dr. D. G. D. Barr at the above address. -fatal, Case 1 ; severely affected, Cases 2, 3, and 4; mildly affected, Cases 5 to 16 . The severe poisonings were characterized by significant early symptoms such as profuse gastrointestinal haemorrhage, undue drowsiness or coma, and cardiovascular collapse in three cases. The survivors were in hospital for 39, 16, and 7 days in Cases 2, 3, and 4 respectively. The mild cases had vomiting without frank haematemesis, only transient drowsiness or pallor, and no cardiovascular collapse. Their clinical progress was uneventful and the average stay in hospital was three days (except Case 7, see below).

The patients were managed along standard lines with gastric lavage on admission and supportive therapy, including intravenous fluids in the more severe cases. Cases 1 and 2 received D.T.P.A. ; the remainder were treated with desferrioxamine, and a variety of dosage schedules were employed for parenteral administration. The use of an oral chelating agent to bind unabsorbed iron remaining in the gut is widely advocated. Our patients received from nil up to $5 \mathrm{~g}$. of desferrioxamine by intragastric tube at the onset of treatment.

The first few hours after ingestion of iron are probably the critical period for chelation therapy (Ciba, 1965 ; Powell and Dugdale, 1964), nearly $90 \%$ of deaths occurring in the first 48 hours (Aldrich, 1958). A summary of our data during this period is given in Table $I$.

Serum and urinary iron levels were followed for a total of nine and eight days in Cases 2 and 3 respectively. The remaining cases had two 24-hour urine collections as recorded in Table I, and in four cases a further 24-hour output was assessed. None of these third-day collections showed significantly increased iron excretion.

\section{Case 1. Fatality}

One and a half hours before admission this child took at least 20 ferrous sulphate tablets. She vomited and had loose stools, and on examination was pallid and responded only to painful stimuli. Gastric lavage yielded fresh blood and remnants of tablets. Two hours after ingestion she collapsed with shallow respiration, cyanosis, and absent peripheral pulses. She was nursed in an oxygen tent and given plasma and whole blood intravenously. Her shock responded, and 12 hours after admission she was awake and alert. She continued to vomit altered blood and had four melaena stools in the first day.

TABLE I.-Summary of Data on 16 Patients During the First 48 Hours

\begin{tabular}{|c|c|c|c|c|c|c|c|c|c|}
\hline \multirow{2}{*}{ Case No. } & \multirow{2}{*}{ Age in Years } & \multirow{2}{*}{ Weight (kg.) } & \multicolumn{3}{|c|}{ Serum Iron ${ }^{*}(\mu \mathrm{g} . / 100 \mathrm{ml})}$. & \multicolumn{2}{|c|}{ Urinary Iront (mg.) } & \multicolumn{2}{|c|}{ Chelation Therapy‡ (g.) } \\
\hline & & & Initial & Day 1 & Day 2 & $0-24 \mathrm{hr}$. & $24-48 \mathrm{hr}$. & Oral & Parenteral \\
\hline $\begin{array}{r}1 \\
2 \\
3 \\
4 \\
5 \\
6 \\
7 \\
8 \\
9 \\
10 \\
11 \\
12 \\
13 \\
14 \\
15 \\
16\end{array}$ & $\begin{array}{l}3 \\
2 \\
2 \\
1 \\
1 \\
2 \\
2 \\
1 \\
1 \\
3 \\
1 \\
2 \\
2 \\
1 \\
5 \\
6 \\
3\end{array}$ & $\begin{array}{l}11.6 \\
11.6 \\
11.1 \\
8.75 \\
11.0 \\
11.25 \\
11.5 \\
13.5 \\
14.1 \\
9.2 \\
13.2 \\
15.0 \\
12.0 \\
18.0 \\
20.1 \\
17.0\end{array}$ & $\begin{array}{l}3,000(6) \\
2,260(1) \\
1,500(3) \\
540(3) \\
630(5) \\
500(3) \\
505(7) \\
500(2) \\
400(4) \\
708 \\
400(1) \\
485 \\
425 \\
428(2) \\
400(2) \\
390(4)\end{array}$ & $\begin{array}{l}42 \overline{-}(24) \\
70(17) \\
148(20) \\
182(18) \\
208(17) \\
150(17) \\
160(8) \\
240(24) \\
140(24) \\
135(24) \\
\overline{1}- \\
125(12)\end{array}$ & $\begin{array}{r}1,880(33) \\
173(48) \\
67 \\
7914 \\
94(44) \\
94-(27) \\
182(40) \\
94(42) \\
2800(25) \\
60(48) \\
140(41) \\
76(25) \\
60(25) \\
129(36)\end{array}$ & $\begin{array}{l}1 \overline{10.4} \\
20.8 \\
13.6 \\
13.0 \\
10.6 \\
5.08 \\
3.5 \\
2.73 \\
2.86 \\
1.58 \\
1.83 \\
1.0 \\
1.09 \\
1.15 \\
0.19\end{array}$ & $\begin{array}{l}1.0 \\
41.0 \\
4.5 \\
0.1 \\
0.1 \\
1.2 \\
0.85 \\
1.4 \\
1.14 \\
0.3 \\
0.63 \\
1.67 \\
0.3 \\
1.3 \\
2.23 \\
0.55\end{array}$ & $\begin{array}{l}\mathrm{Nil} \\
\mathrm{Ni} \\
2.0 \\
5.0 \\
2.0 \\
3.0 \\
2.5 \\
3.0 \\
\mathrm{~N} .0 \\
0.5 \\
\text { N.5 } \\
\text { Niil } \\
\text { Nil } \\
2.0 \\
\text { Nil } \\
\text { Nil } \\
\text { Niil }\end{array}$ & 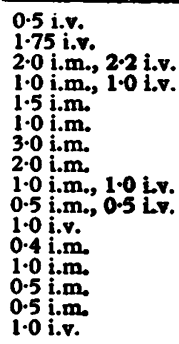 \\
\hline
\end{tabular}


Some 24 hours after ingesting iron she was jaundiced and semicomatose. A firm, tender liver edge was palpable 3 in. $(7.5 \mathrm{~cm}$.) below the right costal margin. Biochemical investigations showed serum sodium $159 \mathrm{mEq} / 1$., potassium $4.5 \mathrm{mEq} / \mathrm{l}$., chloride 104 $\mathrm{mEq} / \mathrm{l}$. The $\mathrm{CO}_{2}$ combining power was $15 \mathrm{mEq} / \mathrm{l}$. The serum bilirubin was $9.1 \mathrm{mg} . / 100 \mathrm{ml}$. with a direct bilirubin of $6.7 \mathrm{mg} . / 100$ ml., alkaline phosphatase 27 King-Armstrong units, S.G.P.T. 232 sigma-Frankel (S.F.) units, and the plasma glucose $5 \mathrm{mg} . / 100 \mathrm{ml}$.

After $50 \%$ glucose and $10 \%$ laevulose intravenously the blood sugar rose to $1,093 \mathrm{mg} . / 100 \mathrm{ml}$. and remained persistently high. Her level of consciousness improved, but within four hours she lasped into coma and her acidosis progressed with a $\mathrm{CO}_{2} \mathrm{com}$ bining power of $6 \mathrm{mEq} / 1$. At 26 hours after ingestion D.T.P.A. became available and she was given $500 \mathrm{mg}$. by infusion in four hours. At 33 hours the serum iron was $1,880 \mu \mathrm{g} . / 100 \mathrm{ml}$. She passed only $20 \mathrm{ml}$. of urine shortly before death, and this contained $1 \mathrm{mg}$. of iron. Supportive management with further infusions of blood and sodium lactate failed to improve her general state. Vomiting of fresh blood continued, and she became restless, then deeply unconscious. Respirations were shallow, and 45 hours after her ingestion of iron she died. At necropsy haemorrhagic gastritis and acute hepatic necrosis were found.

\section{Case 2. Severe (D.T.P.A. Therapy)}

Two hours before admission this boy took 30 to 40 ferrous sulphate tablets. Within half an hour he became collapsed and drowsy and was vomiting reddish-brown material containing fragments of iron tablet. On examination he was pale and lethargic, though rousable. The pulse was of poor volume at $160 / \mathrm{min}$., and the blood pressure $135 / 75 \mathrm{~mm}$. Hg. The stomach was washed out and sodium bicarbonate instilled. Initial investigation showed no electrolyte imbalance. At six hours after ingestion the serum iron was found to be $3,000 \mu \mathrm{g} . / 100 \mathrm{ml}$. and the $\mathrm{CO}_{2}$ content had fallen to $13 \mathrm{mEq} / 1$. Intravenous glucose and electrolyte solution was infused, and at eight hours after ingestion D.T.P.A. was added. He had no chelating drug by mouth. At 13 hours he remained drowsy and limp, with a tachycardia and a blood pressure of 95/ $60 \mathrm{~mm}$. Hg. Stools were positive for occult blood. At 24 hours he was clinically improved and more responsive. The serum iron had fallen to $424 \mu \mathrm{g} . / 100 \mathrm{ml}$. The acidosis was corrected and the blood glucose was $131 \mathrm{mg} . / 100 \mathrm{ml}$. Intravenous fluids with D.T.P.A. were continued over the first four days and serial estimations of serum and urinary iron made (see Table II).

\begin{tabular}{|c|c|c|c|}
\hline $\begin{array}{l}\text { Serum Iron* } \\
(\mu \mathrm{g} . / 100 \mathrm{ml} .)\end{array}$ & $\begin{array}{l}\text { 24-hour Urinet } \\
\text { Volume (ml.) }\end{array}$ & $\begin{array}{c}\text { Urinary Iron } \\
\text { (mg.) }\end{array}$ & $\begin{array}{l}\text { D.T.P.A. Dosage and Time } \\
\text { of Administration } \neq\end{array}$ \\
\hline $\begin{array}{l}3,000(6) \\
424(24)\end{array}$ & 470 & $10 \cdot 4$ & 1.25 g. i.v. $(8-24$ hr.) \\
\hline $\begin{array}{l}273(31) \\
173(48)\end{array}$ & 760 & $41 \cdot 0$ & 0.50 g. i.v. $(24-48 \mathrm{hr})$. \\
\hline & 680 & 3.0 & 0.75 g. i.v. $(48-72 \mathrm{hr})$. \\
\hline & 330 & 1.8 & 0.50 g. i.v. $(72-96 \mathrm{hr})$. \\
\hline 114 (day 8) & $\begin{array}{l}132 \\
275 \\
275 \\
720 \\
240\end{array}$ & $\begin{array}{l}1 \cdot 0 \\
2.5 \\
6.0 \\
5.1 \\
1.3\end{array}$ & \\
\hline
\end{tabular}

\section{- Figures in parentheses indicate time from ingestion in hours.}

\section{+ Successive 24-hour urine collections
$\ddagger$ From the time of ingestion in hours.}

On the third day the liver edge was palpable $1 \frac{1}{2}$ in. $(3.8 \mathrm{~cm}$.) below the right costal margin, the S.G.O.T. was 108 units and S.G.P.T. 92 S.F. units. The blood glucose was $130 \mathrm{mg} . / 100 \mathrm{ml}$. The serum iron had fallen further to $173 \mu \mathrm{g} . / 100 \mathrm{ml}$. The urinary output of amino-acid nitrogen was estimated during the first 10 days and was maximal during the fourth and fifth days with levels of 258 and $230 \mathrm{mg}$. respectively. There was a slight concomitant albuminuria (30 to $100 \mathrm{mg} . / 100 \mathrm{ml}$.). With oral feeding his vomiting restarted and the remainder of the week's fluids had to be given intravenously. He was still drowsy and disinterested in his surroundings. The serum iron was $114 \mu \mathrm{g} . / 100 \mathrm{ml}$. and the total ironbinding capacity $613 \mu \mathrm{g} . / 100 \mathrm{ml}$. plasma albumin $4.1 \mathrm{~g} . / 100 \mathrm{ml}$., globulin 1.55 g./100 ml., S.G.O.T. 46 S.F. units, S.G.P.T. 30 S.F. units, and blood urea nitrogen $16 \mathrm{mg} . / 100 \mathrm{ml}$.; the standard electrolytes were within normal limits.
On the tenth day his mental state was greatly improved, but he was unsteady in the sitting position. At two weeks he was fully orientated and taking semisolids. He remained ataxic over the next fortnight but had no focal neurological signs. The electroencephalograph showed a tendency to hypersynchrony, which had improved three weeks later. Liver-function tests were normal and creatinine clearance was unimpaired. Barium studies showed a suggestion of narrowing in the pyloroduodenal region. When reviewed one year later he was asymptomatic and his development unretarded. Physical examination showed no abnormality. His haemoglobin and liver-function tests were normal and bariummeal examination showed no delay in gastric emptying.

\section{Case 3. Severe (Desferrioxamine Therapy)}

This child was admitted one hour after ingesting an unknown number of ferrous sulphate tablets. She had been drowsy and had vomited. On examination she was apathetic and pale but not shocked. Her clothes were stained with brown vomitus and she had a remarkable "rusty" metallic smell. Initial investigation showed a serum iron of $2,260 \mu \mathrm{g} . / 100 \mathrm{ml}$., normal blood electrolytes, and a $\mathrm{CO}_{2}$ combining power of $19 \mathrm{mEg} / 1$. Gastric lavage produced dark-red fluid containing blood and fragments of iron tablet. Desferrioxamine was given as shown in Table III and chelation therapy continued for three days. Serial 24-hour urine collections for eight days were estimated for iron content. The urine was an orange-red colour in the first 24 hours, amber in the second period, and normally coloured thereafter. After admission her level of consciousness improved and by eight hours she was alert and responsive. Within six hours the serum iron had fallen to 620 $\mu \mathrm{g} . / 100 \mathrm{ml}$. On the second day the S.G.P.T. was 26 S.F. units and S.G.O.T. 73 S.F. units Blood glucose remained normal and there was no fall in $\mathrm{CO}_{2}$ combining power. The total urinary amino-acid nitrogen on days 2 to 8 was 79,62,72, 65, 37, 43, and 31 mg. respectively.

TABLB III.-Case 3. Serial Observations During Chelation Therapy

\begin{tabular}{|c|c|c|c|}
\hline $\begin{array}{l}\text { Serum Iron* } \\
\text { ( } \mu \mathrm{g} . / 100 \mathrm{ml} .)\end{array}$ & \begin{tabular}{|c|} 
24-hour Urinet \\
Volume (ml.)
\end{tabular} & $\begin{array}{l}\text { Urinary Iron } \\
(\mathrm{mg} .)\end{array}$ & $\begin{array}{l}\text { Desferrioxamine Dosage } \\
\text { and Time of Administration }\end{array}$ \\
\hline $\begin{array}{c}2,260(1 \ddagger) \\
620(6) \\
70(17)\end{array}$ & 400 & 20.8 & 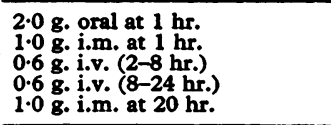 \\
\hline \multirow[t]{2}{*}{$67(41)$} & 1,120 & 4.5 & 1.0 g. i.v. $(24-48 \mathrm{hr})$. \\
\hline & 600 & $2 \cdot 4$ & 0.4 g. i.v. $(48-72 \mathrm{hr}$.) \\
\hline 87 (day 6) & $\begin{array}{l}910 \\
400 \\
470 \\
420 \\
300\end{array}$ & $\begin{array}{l}2.5 \\
1.52 \\
0.22 \\
0.19 \\
0.15\end{array}$ & \\
\hline
\end{tabular}

* Figures in parentheses indicate time from ingestion in hours.

$¥$ From the time of ingestion in hours.

One week after admission she was symptom-free and showed no neurological deficit. The haemoglobin was $73 \%(10.7 \mathrm{~g} . / 100 \mathrm{ml}$.) and mean corpuscular haemoglobin concentration $33 \%$. Blood electrolytes were normal, S.G.O.T. 37 S.F. units, S.G.P.T. 15 S.F. units, plasma albumin $4.8 \mathrm{~g} . / 100 \mathrm{ml}$., and globulin $1.2 \mathrm{~g} . / 100 \mathrm{ml}$. The serum iron was $87 \mu \mathrm{g} . / 100 \mathrm{ml}$. and the total iron-binding capacity $373 \mu \mathrm{g} . / 100 \mathrm{ml}$. Subsequent investigation by barium meal, intravenous pyelography, and electroencephalogram showed no abnormality. One month later she remained well with haemoglobin of $80 \%$ (11.7 g./100 ml.) and serum iron $104 \mu \mathrm{g} . / 100 \mathrm{ml}$.

\section{Case 7. Mild : Complicated Convalescence}

Two hours before admission this child took 20 ferrous sulphate tablets and vomited food containing flecks of blood. On examination she was pale, subdued, and hypotonic. The pulse rate was $150 / \mathrm{min}$. and the systolic blood pressure $100 \mathrm{~mm}$. Hg. Initial investigations showed serum iron $500 \mu \mathrm{g} . / 100 \mathrm{ml}$., the blood electrolytes were normal, and the $\mathrm{CO}_{2}$ combining power was $19 \mathrm{mEq} / \mathrm{l}$. Chelation therapy was given as summarized in Table I. Over the first 24 hours vomiting persisted and at times contained altered blood, but there was no hypotension or cerebral depression. The 
blood electrolytes remained normal, the plasma glucose was 65 $\mathrm{mg} .1100 \mathrm{ml}$. and the S.G.P.T. 23 S.F. units. By 48 hours she had improved and was taking a full diet. Five days after admission she became markedly anorexic and vomiting restarted. The stools were pale, but she was not jaundiced and had no palpable hepatomegaly. Liver-function tests showed bilirubin $0.3 \mathrm{mg} . / 100 \mathrm{ml}$., alkaline phosphatase 11.4 K.A. units, S.G.P.T. 11 S.F. units, and thymol turbidity 5.6 units. At this stage her haemoglobin was $80 \%$ $(11.7 \mathrm{~g} . / 100 \mathrm{ml}$.$) and the serum iron had fallen to 76 \mu \mathrm{g} . / 100 \mathrm{ml}$. A five-day stool collection showed steatorrhoea with an average daily fat excretion of $6.2 \mathrm{~g}$. She developed a moist cough and was treated with penicillin. $X$-ray examination of the chest was negative. By 14 days after admission her appetite had improved, she had gained weight, and her stools were normal in appearance.

At follow-up one year later she had been well apart from a further attack of bronchitis. Bowel function and stool appearance remained normal. She was a satisfactory height and weight for her age, and systematic examination showed no abnormality. The haemoglobin was $86 \%$ (12.6 g. $/ 100 \mathrm{ml}$.) with an M.C.H.C. of $32 \%$. Serum iron was $60 \mu \mathrm{g} . / 100 \mathrm{ml}$. and total iron-binding capacity $318 \mu \mathrm{g} . / 100 \mathrm{ml}$.

\section{Results of Chelation Therapy}

\section{Biochemical Effects}

Case 1 received $500 \mathrm{mg}$. of D.T.P.A. 26 hours after ingesting iron. The serum iron at 33 hours was $1,880 \mu \mathrm{g} . / 100 \mathrm{ml}$. and death occurred at 45 hours. She remained oliguric and secreted only $20 \mathrm{ml}$. of urine, which contained $1 \mathrm{mg}$. of iron. In severe intoxication (Cases 2, 3, and 4), where the initial serum iron was of the order of 1,500 to $3,000 \mu \mathrm{g} . / 100 \mathrm{ml}$., parenteral administration of $1.75 \mathrm{~g}$. of D.T.P.A. (in Case 2) or $4.2 \mathrm{~g}$. and 2 g. of desferrioxamine (in Cases 3 and 4) reduced the serum iron level to normal in the first 48 hours. In the same period urinary excretion of iron was considerable at 51.4, 25.3, and $13.7 \mathrm{mg}$. in these three patients. Case 2 received no chelating agent by mouth; Case 3 was given $2 \mathrm{~g}$. of desferrioxamine, and Case $45 \mathrm{~g}$. of desferrioxamine by intragastric tube on admission. The serial observations on Case 2 are of interest (see Table II). In the first 48 hours of chelation therapy a massive amount of iron was passed in the urine. Further therapy with D.T.P.A. during days 3 and 4 produced a relatively small iron excretion. In spite of this there appeared to be a secondary rise in iron excretion on days 7 and 8 unrelated in time to the chelating drug. The rise occurred with increased intravenous fluids after a period of relative oliguria, and suggests that an adequate urinary output may improve iron excretion in this situation.

The cases of mild poisoning (Cases 5 to 16), in which the initial serum iron ranged from 390 to $708 \mu \mathrm{g} . / 100 \mathrm{ml}$., received parenteral administration of from 0.4 to $3 \mathrm{~g}$. of desferrioxamine over the first two days. The serum iron levels were mostly normal by 48 hours. The 48-hour urinary excretion of iron ranged from 0.74 to $5.93 \mathrm{mg}$. in Cases 7 to 16, but Cases 5 and 6 showed appreciably higher excretions at 13.1 and 11.8 mg. respectively. Serial observations suggest that a shorter course of chelating agent would have been sufficient in some of these mild poisonings. Thus, in Case 7, $2 \mathrm{~g}$. of desferrioxamine caused $5.08 \mathrm{mg}$. of iron to be excreted in the first 24 hours. Further dosage of $1 \mathrm{~g}$. of desferrioxamine resulted in only a modest iron excretion of $0.85 \mathrm{mg}$. in the period $24-48$ hours and $0.73 \mathrm{mg}$. from $48-72$ hours. Schedules for dosage of oral chelating agent in these mild iron poisonings have varied from nil to $3 \mathrm{~g}$. of desferrioxamine given by intragastric tube at the outset of treatment.

\section{Side-effects}

No toxic effects attributable to D.T.P.A. or desferrioxamine were observed in this series. One patient (Case 7) had a temporary and unexplained steatorrhoea during convalescence from mild iron poisoning. In two of the severe cases a transient amino-aciduria was observed, but this could be explained by the toxic effects of iron on the liver or renal tubule.

\section{Mortality and Morbidity}

One child died. The survivors have been followed up for periods ranging from two months to two years. One child (Case 3) who had a previous history of febrile convulsion presented with a pyrexial illness and abnormal drowsiness five months after her iron ingestion. Her electroencephalograph suggested left-sided brain damage. She subsequently demonstrated a major problem with hyperkinetic and destructive - behaviour and temper tantrums. In the other children there have been no symptoms or findings on physical examination to suggest neurological, gastrointestinal, or other sequelae. In the severe cases follow-up investigations have shown no abnormality in the blood count, serum iron level, or barium-meal examination. Liver-function tests were normal except in Case 4, who had S.G.P.T. of 66 S.F. units, and cephalin-cholesterol flocculation test of $4+$ two months after ingesting iron. These values had been normal in the week following iron ingestion and had reverted to S.G.P.T. 28 and cephalin-cholesterol flocculation test $1+$ at six months from the time of admission.

\section{Discussion}

\section{Biochemical Effects}

In the published literature we have found details of 44 cases of iron poisoning in children treated with these iron-chelating drugs.

One child (Gokulanathan et al., 1963) had edetic acid (E.D.T.A.) and partial exchange transfusion before receiving D.T.P.A. in a dosage of $1.2 \mathrm{~g}$. over a period of six days. There is no record of serum or urinary iron levels, but the child was critically ill and eventually made a good recovery. A second case treated with D.T.P.A. is reported by Rubin (1964). The remaining children received desferrioxamine. Case 1 of Dugdale and Powell (1964) had a fatal outcome. Having received edetic acid initially, he was given desferrioxamine in a dosage of $250 \mathrm{mg}$. intravenously at 20 hours, but died at 30 hours, when a serum iron of $2,900 \mu \mathrm{g} . / 100 \mathrm{ml}$. was recorded. His case was therefore similar to our own Case 1 (see above). These were cases of very severe intoxication in which specific chelation therapy was unavoidably delayed ( 20 and 26 hours), rather low dosage was used, and iron excretion was slight $(1 \mathrm{mg}$.) in the case where this was measured. This experience is not regarded as an adverse reflection of the drug's effectiveness, but rather illustrates the poor prognosis associated with delay in treatment. Santos and Pisciotta (1964) described one case with moderately severe symptoms, including vomiting, diarrhoea, pallor, and depressed consciousness. The initial serum iron was $575 \mu \mathrm{g} . /$ $100 \mathrm{ml}$., and $3.05 \mathrm{mg}$. of iron was excreted in the first 38 hours. In this period $0.8 \mathrm{~g}$. of desferrioxamine was given intravenously and $3 \mathrm{~g}$. orally.

Of the 12 children whose cases were reported by Whitten et al. (1965) one had prolonged coma and a serum iron of $370 \mu \mathrm{g} . /$ $100 \mathrm{ml}$. , and iron excretion was not studied. The remainder

TABLE IV.-Summary of Chelation Data in Very Severe Cases of Iron

\begin{tabular}{|c|c|c|c|c|}
\hline \multirow{2}{*}{ Source } & \multirow{2}{*}{$\begin{array}{c}\text { Initial } \\
\text { Serum Iran } \\
(\mu \mathrm{g} . / 100 \mathrm{ml} .)\end{array}$} & \multirow{2}{*}{$\begin{array}{l}\text { Urine Iron } \\
\text { (mg.) }\end{array}$} & \multicolumn{2}{|c|}{$\begin{array}{l}\text { Desferrioxamine } \\
\text { Therapy (g.) }\end{array}$} \\
\hline & & & Oral & Parenteral \\
\hline $\begin{array}{l}\text { Henderson et al. (1963) } \\
\text { Dugdale and Powell } \\
\text { (1964) Case II } \\
\text { Shapiro and Barbezat } \\
\text { (1964). } \\
\text { McEnery and Miack } \\
\text { (1964). . } \\
\text { Jacobs et al. (1965) Case i }\end{array}$ & $\begin{array}{c}2,550 \\
4,800 \\
- \\
1,653 \\
1,162\end{array}$ & $\begin{array}{c}24 \cdot 7 / 35 \mathrm{hr} . \\
5 \cdot 6 / 24 \mathrm{hr} . \\
10-02 / 48 \mathrm{hr} . \\
16 \cdot 8 / 24 \mathrm{hr} . \\
6 \cdot 75 / 24 \mathrm{hr} .\end{array}$ & $\begin{array}{r}5.0 \\
6.0 \\
10.0 \\
5.0 \\
8.0\end{array}$ & $\begin{array}{l}1.6 / 24 \mathrm{hr} . \\
1.2 / 48 \mathrm{hr} . \\
3.96 / 48 \mathrm{hr} . \\
2.5 / 48 \mathrm{hr} \text {. } \\
1.5 / 48 \mathrm{hr} \text {. }\end{array}$ \\
\hline
\end{tabular}


had no progression of symptoms attributable to iron poisoning, and serum iron levels were 300 to $792 \mu \mathrm{g} . / 100 \mathrm{ml}$. Urine iron levels were of the order of 0.5 to $6 \mathrm{mg}$. in 24 hours, with the exception of Case J.S. (see Table V). Dosage of desferrioxamine ranged from 0.5 to $1.5 \mathrm{~g}$. intravenously and 5 to $10 \mathrm{~g}$. by gavage. Jacobs et al. (1965) report five cases. One of these was severe and is included in Table IV. The others had no severe symptoms, serum iron levels ranging from 400 to 503 $\mu \mathrm{g} . / 100 \mathrm{ml}$. and iron excretion from 0.5 to $1.52 \mathrm{mg}$. in 24 hours. Desferrioxamine was used in a dosage of $1 \mathrm{~g}$. intravenously and $8 \mathrm{~g}$. by mouth.

TABLE V.-Cases of Mild/Moderate Severity with High Iron Excretion

\begin{tabular}{|c|c|c|c|}
\hline Source & $\begin{array}{c}\text { Initial } \\
\text { Serum Iron } \\
\text { ( } \mu \mathrm{gg} . / 100 \mathrm{ml} .) \\
\end{array}$ & $\begin{array}{l}\text { Urine Iron } \\
\text { (mg.) }\end{array}$ & $\begin{array}{l}\text { Desferrioxamine } \\
\text { Therapy }\end{array}$ \\
\hline $\begin{array}{l}\text { Whitten et al. (1965) Case } \\
\text { J.S. } \text { McEnery and Greengard }\end{array}$ & 792 & $25 / 24 \mathrm{hr}$. & 5.0 g. oral, 0.8 g. i.v. \\
\hline $\begin{array}{ll}\text { (1966) Case } 17 & \\
\text { Present series Case } 5 & \ldots \\
\text { Present series Case } 6\end{array}$ & $\begin{array}{l}469 \\
540 \\
630\end{array}$ & $\begin{array}{l}17.57 / 48 \mathrm{hr} . \\
13 \cdot 1 / 48 \mathrm{hr} . \\
11.8 / 48 \mathrm{hr} .\end{array}$ & $\begin{array}{l}5.0 \mathrm{~g} \text {. oral, } 3.72 \mathrm{~g} . \mathrm{i} . \mathrm{.} \\
2 \cdot 0 \mathrm{~g} \text { oral, } 1.5 \mathrm{~g} \text {. i.m } \\
3.0 \mathrm{~g} \text { oral, } 1.0 \mathrm{~g} \text {. i.m. }\end{array}$ \\
\hline
\end{tabular}

McEnery and Greengard (1966) record 20 hospital admissions for ingestion or suspected ingestion of iron. The most severe case (No. 4) had been previously reported (McEnery and Mack, 1964), and is included in Table IV. Of the others, seven were described as "alert" or in "good" condition. The remainder showed lethargy or irritability, and in two there were signs of shock. Though serum iron levels did not always correlate well with the history and symptomatology, eight of the children had serum iron levels of under $200 \mu \mathrm{g} . / 100 \mathrm{ml}$. and the maximum recorded in the others was $536 \mu \mathrm{g} . / 100 \mathrm{ml}$. Urinary iron excretion varied from nil to $5.26 \mathrm{mg}$. in the first 24 hours (except Case 17, see Table V). In these cases of mild to moderate severity dosage of desferrioxamine varied from nil to $2.2 \mathrm{~g}$. parenterally in the first 48 hours and from 0.2 to $5 \mathrm{~g}$. by mouth at the onset of treatment.

The published cases, which were clinically severe and in which a fatal outcome may well have been averted, are summarized in Table IV. In these, initial serum iron levels were of the order of 1,000 to $5,000 \mu \mathrm{g} . / 100 \mathrm{ml}$. Desferrioxamine in a dosage of 1.2 to $4 \mathrm{~g}$. in the first 48 hours produced iron excretions which varied from $5.6 \mathrm{mg}$. $/ 24$ hours to $24.7 \mathrm{mg} . / 35$ hours. Our own Cases 2, 3, and 4 may be included with this group, and comparable details are given in Table I.

In the published cases of mild to moderate severity where the initial serum iron was of the order of $500 \mu \mathrm{g} . / 100 \mathrm{ml}$., parenteral administration of 0.5 to $2 \mathrm{~g}$. of desferrioxamine in the first 24 hours produced an iron excretion of 0.5 to $6 \mathrm{mg}$. in this period. There are four recorded exceptions to this (see Table V). In each of these the clinical effects might be classified as mild or moderate, the serum iron levels were not grossly elevated, but the urinary excretion of iron after chelation was considerable and comparable with the most severe intoxications. This may represent an important group who would have deteriorated to severe intoxication if this large amount of iron had not been removed.

\section{Side-effects}

In reported series the only well-established adverse reaction appears to be the occurrence of hypotension after rapid intravenous infusion of desferrioxamine. This is described by Whitten et al. (1965) as present in two out of three children given doses of 0.8 to $1.5 \mathrm{~g}$. in 15 minutes. Rapid intravenous injection of this order is contraindicated. Hypotension is avoided by keeping within the recommended dosage rate of not more than $15 \mathrm{mg}$. $/ \mathrm{kg}$./hour (Ciba, 1965). Intramuscular injection may cause local pain (Ciba, 1965), but this has not been commented on in the published cases. D.T.P.A. injection may be very painful (Robertson et al.. 1963) unless given with procaine.
The excretion of ferrioxamine $B$ has apparently caused exacerbation of pyelonephritis (Ciba, 1965), and a 56-year-old man with secondary haemachromatosis and megaloblastic anaemia had an acute haemorrhagic diathesis with thrombocytopenia after six days on desferrioxamine. In this case a causal relation with the drug was felt to be unlikely (Moeschlin et al., 1962).

In experimental studies, opacity of the cornea and lens has been observed in dogs after prolonged usage of desferrioxamine (Westlin, 1966), and 10 of the children quoted by McEnery and Greengard (1966) were examined for this at three and six months with negative results. Studies in dogs by Whitten et al. $(1965,1966)$ showed a hypotensive effect after infusion of desferrioxamine. Dosages of $3-30 \mathrm{mg} . / \mathrm{kg}$. in one minute and $1.5 \mathrm{mg} . / \mathrm{kg} . / \mathrm{min}$. for six hours were used; these considerably exceeded the recommended dosage for children. The irondesferrioxamine complex (ferrioxamine) could also cause hypotension, and was absorbed when given in large doses by mouth. Both orally and intravenously, ferrioxamine was toxic to the animal. This suggests that there may be a potential hazard of drug toxicity in cases of iron poisoning given large doses of desferrioxamine by mouth or by injection. Within the limits of the recommended dosage there is no evidence so far that this has been important in clinical practice. The risks might be increased if acute renal failure prevented excretion. In this event dialysis will remove ferrioxamine, though this procedure did not improve the survival rate in dogs (Whitten et al., 1966).

\section{Mortality and Morbidity}

A mortality rate of $45-50 \%$ for severe iron poisoning is often quoted and is based on the work of Aldrich (1958). That study of 42 cases reviewied the literature at a time when stress was being laid on the potential dangers and the pathological features of the condition. In a later résumé of the literature, Whitten et al. (1965) showed that in severe cases characterized by coma and shock all 10 children who received no treatment died. Among 26 who received only supportive therapy (transfusions, etc.) there were 12 deaths, and among 10 cases treated with definitive therapy such as dimercaprol (B.A.L.), edetic acid, and exchange transfusion two deaths occurred. With the use of the new iron-chelating drugs there are two recorded deaths in 11 cases considered to have been at mortal risk. These 11 comprise the cases shown in Table IV. Cases 1 to 4 in Table I, Case 1 of Dugdele and Powell (1964), and the case of Gokulanathan et al. (1963). The mortality in this group occurred where specific iron-chelation therapy was delayed beyond 20 hours, and at this advanced stage a fatal outcome cannot be taken to imply failure of the chelating drug. An improved survival rate as an index of the efficacy of the new chelating drugs is difficult to demonstrate, as iron poisoning is an uncommon cause of death. In Scotland as a whole there have been nine recorded childhood deaths from iron poisoning in 15 years (Registrar General of Scotland, 1950-64).

Of the 24 survivors in the series reported by Aldrich (1958) six later developed signs of cicatricial stenosis of the stomach or duodenum and one died at this stage from profound malnutrition. The others required major surgery. Since the introduction of D.T.P.A. and deferrioxamine the records of the nine survivors from severe iron poisoning show no instances of this complication. In this respect orally administered chelating agent may be exerting an important local effect in reducing mucosal damage. Further information from follow-up studies is limited, but it may reasonably be anticipated that effective chelation therapy will reduce the incidence of morbidity due to gastrointestinal, hepatic, or neurological sequelae.

Thus recent reports probably reflect a distinct improvement in prognosis for morbidity and mortality. Further recorded experience, particularly of the severe case, is needed to confirm this trend. 


\section{Recommendations}

Our policy at present is to admit to hospital all children suspected of swallowing iron. Every case has gastric lavage and $5 \mathrm{~g}$. of desferrioxamine instilled into the stomach.

If there is a definite history that only two or three tablets have been taken, and no symptoms have developed several hours after ingestion, then a modified regimen using an initial $1 \mathrm{~g}$. of desferrioxamine intramuscularly is adopted. An initial serum iron of less than $500 \mu \mathrm{g} . / 100 \mathrm{ml}$. is taken as supportive, but not absolute, evidence of mild poisoning. The pulse, blood pressure, and level of consciousness are then carefully monitored and all urine is collected and examined for the reddishorange discoloration of ferrioxamine. In all cases but the most trivial a second intramuscular injection of $500 \mathrm{mg}$. of desferrioxamine is given at 12-24 hours.

If the history is doubtful or suggests the ingestion of any quantity of tablets-for example, more than five-particularly if only. a short period has elapsed since ingestion, or if there have been any serious symptoms, then a continuous intravenous infusion is begun and $2 \mathrm{~g}$. of desferrioxamine is given by this route over the first 24 hours. The rate of infusion should not exceed $15 \mathrm{mg}$. of desferrioxamine per kg. body weight per hour. An initial serum iron of more than $500 \mu \mathrm{g} . / 100 \mathrm{ml}$. is taken as suggestive of serious poisoning. Further desferrioxamine would be indicated if there was any progression of symptoms, if the urine remained orange in colour (ferrioxamine), or if the serum iron was greater than $200 \mu \mathrm{g} . / 100 \mathrm{ml}$. at the end of this period.

\section{Summary}

Sixteen cases of accidental iron ingestion treated with diethylenetriamine penta-acetic acid (D.T.P.A.) or desferrioxamine are described in detail. One fatality was associated with delay in the onset of specific chelation therapy. In three severe cases recovery was associated with large excretions of iron. Chelation data in apparently mild poisoning showed that two out of 12 cases excreted large amounts of iron, suggesting that potentially more severe intoxication had been averted. No toxic effects attributable to D.T.P.A. or desferrioxamine occurred. At follow-up one severe case had possible neurological sequelae. There were no instances of gastrointestinal stenosis. From these results and a review of the literature it can be concluded that these drugs are biochemically effective, are largely free of side-effects, and have probably improved the prognosis for survival and morbidity. Further evidence is needed from cases of severe iron intoxication.

ADDENDUM.-Since this report was prepared a further paper on the use of desferrioxamine in acute iron poisoning has been published (Leikin et al., 1967). This recommends that this chelating agent be not used routinely in mild cases, which differs from our suggested policy.

We wish to acknowledge the advice and guidance of Professor J. O. Forfar, department of child life and health, University of Edinburgh, and the helpful co-operation of the consultant paediatricians of the Royal Hospital for Sick Children and the Children's Units, Northern Hospital Group, Edinburgh, in allowing us to study patients under their care. Dr. S. L. Tompsett, of the department of clinical chemistry, University of Edinburgh, and the staff of the Royal Hospital for Sick Children and Northern Group Laboratories kindly undertook the biochemical estimations.

\section{REFERENCES}

Aldrich, R. A. (1958). In Iron in Clinical Medicine, edited by R. $O$. Wallerstein and S. R. Mettier, p. 93. California.

Bannerman, R. M., Callender, S. T., and Williams, D. L. (1962). Brit. med. F., 2, 1573.

Brit. med. F., 1963, 2, 1353.

Brit. med. Y., 1965, 1, 366.

Ciba Laboratories (1965). Desferal: A specific Iron Chelating Agent for the treatment of Chronic Iron Overload, Acute Iron Poisoning and for Diagnosis. Horsham.

Dugdale, A. E., and Powell, L. W. (1964). Med. 7. Aust., 2, 990.

Gokulanathan, K. S., Baird, R. L., Reichelderfer, T. E., and Rubin, M. (1963). Georgetown med. Bull., 16, 238.

Henderson, F., Vietti, T. J., and Brown, E. B. (1963). 7. Amer. med. Ass., 186, 1139.

Jacobs, J., Greene, H., and Gendel, B. R. (1965). New Engl. F. Med., 273, 1124.

Lancet, 1964, 1, 708.

Leikin, S., Vossough, P., and Mochir-Fatemi, F. (1967). F. Pediat., 71,

McEnery, J. T., and Greengard, J. (1966). F. Pediat., 68, 773.

McEnery, J. T., and Mack, R. B. (1964). Illinois med. f., 126, 550.

Moeschlin, S., et al. (1962). Schweiz. med. Wschr., 92, 1295.

Moeschlin, S., and Schnider, U. (1963). New Engl. J. Med., 269, 57.

Powell, L. W., and Dugdale, A. E. (1964). Lancet, 1, 934.

Ramsay, W. N. M. (1958). In Advances in Clinical Chemistry rol. 1, p. 2, edited by H. Sobotka and C. P. Stewart. New York.

Registrar General for Scotland (1950-1964). Annual Report. Deaths Recorded as Accidental Poisoning.

Robertson, E. F., Marwell, G. M., and Elliott, R. B. (1963). Med. J. Aust., 2, 705.

Rubin, M. (1964). In Chelation Therapy, edited by A. Soffer. Springfield, Illinois.

Rubin, M., and Princiotto, J. V. (1960). Ann. N.Y. Acad. Sci., 88, 450.

Santos, A., and Pisciotta, A. (1964). Amer. F. Dis. Child., 107, 424.

Shapiro, N., and Barbezat, G. O. (1964). S. Afr. med. Y., 38, 461.

Tompsett, S. L. (1965). In Proceedings of the Association of Clinical Biochemists, vol. 3, p. 286.

Tompsett, S. L. (1966). In Bulletin of the International Association of Forensic Toxicologists, vol. 3, p. 3.

Westlin, W. F. (1966). Clinical Investigation Section, Ciba Pharmaceutical Co. Personal communication to McEnery and Greengard (1966).

Whitten, C. F., Chen, Y-c., and Gibson, G. W. (1966). Pediatrics, 38, 102.

Whitten, C. F., Gibson, G. W., Good, M. H., Goodwin, J. F., and Brough, A. J. (1965). Pediatrics, 36, 322. 